\title{
Tensile Properties and Fractographic Analysis of Low Density Polyethylene Composites Reinforced with Chemically Modified Keratin-Based Biofibres
}

\author{
Isiaka Oluwole Oladele ${ }^{1,2^{*}}$, Jimmy Lolu Olajide ${ }^{1,3^{*}}$, Okikiola Ganiyu Agbabiaka ${ }^{1}$, \\ Olawale Opeyemi Akinwumi ${ }^{1}$ \\ ${ }^{1}$ Department of Metallurgical and Materials Engineering, Federal University of Technology, Akure, Nigeria \\ ${ }^{2}$ African Materials Science and Engineering Network (AMSEN) A Carnegie-IAS (RISE) Network, (FUTA Node) \\ Akure, Nigeria \\ ${ }^{3}$ Department of Mechanical Engineering, Elizade University, Ilara-Mokin, Nigeria \\ Email: “wolesuccess2000@yahoo.com, iimmylolu@gmail.com, okisagbas@yahoo.com
}

Received 22 May 2015; accepted 20 July 2015; published 23 July 2015

Copyright (C) 2015 by authors and Scientific Research Publishing Inc.

This work is licensed under the Creative Commons Attribution International License (CC BY).

http://creativecommons.org/licenses/by/4.0/

(c) (i) Open Access

\section{Abstract}

This research has investigated the tensile properties and fractography of animal fibre-reinforced low density polyethylene composites. The composites were synthesized by hot compression moulding using chemically modified white and black cow hair biofibres as the reinforcing phase of composites. Alkaline solutions of varying molarities were used to prepare the chemical treatments in this present study. Tensile properties of the developed composites were evaluated based on molarities of chemical treatment and \% fibre loading. Scanning electron microscopy was used to characterize the morphologies of the fractured surfaces of composites. Obtained tensile test results revealed significant enhancement in the tensile properties of composites, with the optimum combination of tensile properties presented by $2 \mathrm{wt} \%$ white cow hair biofibre reinforcement treated with $0.15 \mathrm{M}$ sodium hydroxide. Observations from the fractographic analysis of the developed composites revealed shearing of the polymer matrix at the fibre-matrix interface and no fibre pullout behaviour.

\section{Keywords}

Animal Fibre, Alkaline Treatment, Fibre-Matrix Interface, Mechanical Behaviour, Polymer Matrix Composites

\footnotetext{
"Corresponding authors.

How to cite this paper: Oladele, I.O., Olajide, J.L., Agbabiaka, O.G. andAkinwumi, O.O. (2015) Tensile Properties and Fractographic Analysis of Low Density Polyethylene Composites Reinforced with Chemically Modified Keratin-Based Biofibres. Journal of Minerals and Materials Characterization and Engineering, 3, 344-352.
} 


\section{Introduction}

Mammalian hairs especially the human hair have been reported by many authors and researchers to exhibit very good physical and mechanical properties, which in turn account for their intrinsic ability to undergo appreciable mechanical stressing and various types of chemical and thermal treatments without sustaining permanent damage [1]-[3]. This unique behaviour of hair has been attributed to the presence of structural proteins which are essentially keratin in the hair fibre [4]. Hair has been defined as a filamentous biomaterial consisting principally of proteins, most especially keratin [5]. These keratins are scaffolding proteins that combine to form a network of intermediate filaments in the cytoplasm of epithelial cells and their foremost function is fundamentally to provide structural maintenance for cells and tissues [6]. Remarkable works of some researchers have shown that the response of hair fibres to mechanical stresses is highly dependent on the stability of the structure of the cortical keratin of hair fibre and this stability is at times affected by heat and chemical treatments depending on the degree of application [7] [8]. Recent research findings have also shown that appropriate chemical treatments can significantly improve the structural integrity of hair fibres without deteriorating their intrinsic properties [9] [10]. In recent times, these attractive properties of hair fibres have impelled materials scientists especially from the developing countries to reassess the economic importance of hair fibres, and in doing so, they are able to unlock a new vista for the industrial applications of hair fibres, as reinforcements for the synthesis of novel composite materials [11] [12].

Historically, the development of hair fibre reinforced composites dated back to the $\mathrm{BC}$ ages, when goat and horse hair fibres were used to reinforce masonry mortar and plaster [13] [14]. However, this application of hair fibres as reinforcements was ephemeral owing to the advent of mineral and synthetic fibres in the ensuing millennia [15] [16]. Although these new fibres demonstrated phenomenal improvement in their applications and in a short time saturated the fibre market, the limitations associated with them in terms of availability, synthesis, pecuniary viability and ecological impact have ultimately obligated materials scientists and engineers of this contemporary era to revisit the prospective applications of animal fibres for composites development [17]-[19]. This revisitation on animal fibres particularly keratin-based fibres for composites development has manifested in quite a remarkable but not exhaustive number of investigations with encouraging results [20] [21]. Dwivedi et al. used human hair fibre to reinforce polypropylene and documented a significant improvement in the mechanical properties of the developed composites; the work of Oladele et al. also showed an improvement in the flexural properties of cow hair fibre reinforced high density polyethylene composites [22] [23]. This present study is aimed at investigating the efficiency and suitability of utilizing cow hair fibres as the reinforcing phase in low density polyethylene polymer matrix.

The first of the polyolefins, Low Density Polyethylene or LDPE, was originally synthesized some fifty years ago by the high pressure polymerization of ethylene. Its relatively low density arises from the presence of a small amount of branching in the chain, on about $2 \%$ of the carbon atoms. This gives a more open structure. It is translucent to opaque, robust enough to be apparently unbreakable and at the same time quite flexible; it may be used at temperatures up to $95^{\circ} \mathrm{C}$ for short periods and at $80^{\circ} \mathrm{C}$ continuously [24]. Despite competition from new contemporary polymers, LDPE continues to be an important plastic grade. In 2013, the worldwide LDPE market reached a volume of about 33 billion dollars (USD) [25]. Applications of LDPE are extensively seen in low load bearing materials such as general purpose tubing, pipette washing equipment, wash bottles, plastic bags for computer components, wire and cable insulations, utensils, playground slides and toys [26]. Despite the vast areas of applications presented by LDPE, its associated drawbacks include low strength and stiffness, susceptibility to stress cracking, flammability, high gas permeability particularly $\mathrm{CO}_{2}$, poor temperature capability and poor weathering resistance [27]. Numerous approaches to progressively surmount these limitations utilizing varieties of reinforcements from microfibres to nanotubes in the matrix of LDPE are voluminously available in existing literature [28]-[30]. Nevertheless, the utilization of cow hair fibres as a potential reinforcement in alleviating these unpromising limitations has not been documented and this in particular, contributes to the novelty of this research.

The relative abundance of cow hair fibres in Nigeria [31], their unsanitary methods of disposal [32], and the exigent compulsion to appreciably promote and concurrently encourage the development of low cost polymer matrix composites in Nigeria, with a view to moderating the dependence of the nation's polymer-consuming industries on foreign polymers [33], are the stimulating objectives for selecting cow hair fibres in this present study. In addition, the selection of sodium hydroxide or $\mathrm{NaOH}$ and potassium hydroxide or $\mathrm{KOH}$ for the purpose of this research is due to their relative availability, cost effectiveness and successful treatment history on natural 
fibres [34].

\section{Materials and Method}

\subsection{Materials}

\subsubsection{Cow Hair Fibres}

White cow tail hair fibres, Zebu breed and black cow tail hair fibres, N'Dama breed were sourced and procured from abattoirs in Akure, Ondo State, Nigeria. The average age of cows from which the hair fibres were scraped is 2 years \pm 6 months. The cows were raised in North-Central Nigeria under free-range system where the temperature across the year varies between $22.55^{\circ} \mathrm{C} \pm 0.423^{\circ} \mathrm{C}$ in the wet season and $33.54^{\circ} \mathrm{C} \pm 0.23^{\circ} \mathrm{C}$ in the dry season [35].

\subsubsection{Chemical Treatments}

The chemicals used for preparing the treatments were sourced and procured from Pascal Scientific Akure, Ondo State, Nigeria.

\subsection{Methods}

\subsubsection{Chemical Treatment of the Cow Hair Fibres}

As-procured black and white cow hair fibres of average diameters $130 \pm 30 \mu \mathrm{m}$ were thoroughly washed with tap water and detergents to remove impurities such as blood stains, oil and grease that stuck to the fibre surface. This was ensued by rinsing with distilled water and drying at a temperature of $26^{\circ} \mathrm{C} \pm 2^{\circ} \mathrm{C}$ for 5 days. The fibres were cut into $45 \mathrm{~mm}$ fibre length to develop two-dimensional near isotropic composite structures. In order to enhance the surface topography and hydrophobicity of the fibres, for appreciable mechanical bonding between fibres and the LDPE polymer matrix, fibres were dipped into predetermined molar concentrations of $0.05,0.10$ and $0.15 \mathrm{M}$ of $\mathrm{KOH}$ and $\mathrm{NaOH}$ treatments having $\mathrm{pH}$ values of 8 , respectively. Subsequently, the chemical treatments containing the fibres were heated in a shaker water bath maintained at $50^{\circ} \mathrm{C}$ for 4 hours to further enhance the adhesive property of fibres.

\subsubsection{Development of the Cow Hair Fibre-Reinforced LDPE Composites}

The animal fibre-reinforced LDPE composites and the control test samples were synthesized by hot compression moulding technique. To produce the composites, the matrix and the fibres were mixed together in predetermined proportions as shown in Table 1.

The materials were weighed on an electronic weighing balance prior their pouring into tensile test moulds, made of steel. To achieve homogeneous mixture of the fibres within the LDPE matrix and a near isotropic structure of the LDPE composites, mixing was done with a mixing spoon. Afterwards, the filled moulds were placed inside a compression moulding machine maintained at $160^{\circ} \mathrm{C}$ for 5 minutes. Upon full compaction of the developed test samples, they were extracted from the mould in a warm condition and allowed to cure in air. The same compositions were used for all the developed composites.

\subsubsection{Tensile Testing}

The tensile properties of the test samples were evaluated using an Instron universal testing machine, Model 1195. The tests were performed at a fixed crosshead speed of $10 \mathrm{~mm} \mathrm{~min}^{-1}$ at $25^{\circ} \mathrm{C}$. Test samples were prepared according to ASTM D412 standard [36]. To ensure accuracy of test results, three repeatability tests were performed on the test samples for each evaluated tensile property.

\subsubsection{Fractographic Analysis}

The fracture behaviour of the developed LDPE composites was studied with scanning electron microscopy, Model

Table 1. Composition of the cow hair fibre-reinforced LDPE composites.

\begin{tabular}{ccccc}
\hline Composition & wt $\%$ & wt $\%$ & 96 & wt $\%$ \\
\hline LDPE & 98 & 94 \\
Fibre & 2 & 4 & 6 \\
\hline
\end{tabular}


JEOL JSM-6480LV. The samples were thoroughly cleaned, air-dried and coated with $100 \AA$ thick platinum in a JEOL sputter ion coater and observations were made at $20 \mathrm{kV}$. Also, to enhance the conductivity of the composite samples, a thin film of platinum was vacuum-evaporated on the test samples prior the microphotography.

\section{Results and Discussion}

\subsection{Tensile Properties}

\subsubsection{Tensile Stress at Peak}

The variation of tensile stress at peak with molar concentrations of the chemical treatments for the cow hair fibre (CHF)-reinforced LDPE composites and the unreinforced LDPE polymer (control) is presented in Figure 1. Observations from this result revealed that increase in molar concentration of the $\mathrm{NaOH}$ treatment is directly proportional to increase in the ultimate tensile strengths of most of the LDPE composites reinforced with $\mathrm{NaOH}$-treated $\mathrm{CHFs}$ and for the $\mathrm{KOH}$ treatment there is no direct relationship between increase in molar concentration of the $\mathrm{KOH}$ treatment and enhancement in the ultimate tensile strengths of the LDPE composites reinforced with $\mathrm{KOH}$-treated CHFs. Also, with respect to \% fibre loading it was observed that there is no consistency in the trend of the LDPE composites relative to tensile stress at peak. This is a clear indication that the fibre population is effectively supported by the LDPE matrix. Categorically, all the developed LDPE composites demonstrated better performances with respect to tensile stress at peak in comparison with the unreinforced LDPE polymer. The superlative performance is given by the LDPE composite reinforced with $0.15 \mathrm{M} \mathrm{NaOH}-$ treated $2 \mathrm{wt} \%$ white cow hair fibre (WCHF) and it is $186.65 \%$ better than the unreinforced LDPE polymer. The least enhancement is given by the LDPE composite reinforced with $0.15 \mathrm{M} \mathrm{KOH}$-treated $4 \mathrm{wt} \%$ black cow hair fibre (BCHF) and it still supersedes the tensile stress at peak of the unreinforced LDPE polymer by $24.99 \%$. This significant enhancement in ultimate tensile strengths of the developed LDPE composites can be attributed to improved hydrophobic nature and surface topography of the chemically treated CHFs which in turn manifested in a very strong interfacial adhesion between the CHFs and the LDPE polymer matrix [37]. The work of many research scholars on the mechanical behaviour of fibre-reinforced polymers have shown that appreciable interfacial adhesion between fibre and matrix allows large fraction of the applied stress to be transferred by shear loading at the fibre-matrix interface via the matrix to the fibres and this in turn increases the magnitude of plastic deformation the material can sustain before fracture [38] [39]. The result of this research is in conformity with their analytical explanation. Furthermore, the effect of fibre length and fibre orientation adopted for the purpose of this research is undoubtedly responsible for the outstanding performance of the LDPE composites. Longer fibre lengths have been reported to give significant enhancement in tensile properties, [40] Amuthakkannan et al., investigated the effect of fibre length on the mechanical properties of basalt fibre-reinforced polymer matrix composites and documented a superlative improvement in the tensile strength of the composite reinforced with $50 \mathrm{~mm}$ basalt fibres in comparison with shorter length of fibres used for their investigation. They attributed this phenomenon to the reduction in the number of fibre ends which serve as sites for localized stress concentration and crack initiation points in the matrix of the material [41]. Also, according to the works of some authors on the mechanics of fibre-reinforced plastics, random orientation of discontinuous fibres evenly dispersed in the matrix of a material either gives the material a three-dimensional or two-dimensional near isotropic structure depending on the fibre length [42] [43]. For an isotropic material it is assumed that stress distribution across the material structure is uniform [44]. Two-dimensional near isotropy adopted for this research could have correspondingly contributed to the observed enhancement in tensile strengths of the developed composites.

\subsubsection{Tensile Stress at Break}

The variation of tensile stress at break with molar concentrations of the chemical treatments for the LDPE composites and the unreinforced LDPE is presented in Figure 2. Observations from this result showed almost a similar trend as was observed in Figure 1. The peculiar difference in this case is that the superlative performance is given by the LDPE composite reinforced with $0.10 \mathrm{M} \mathrm{NaOH}$-treated $2 \mathrm{wt} \% \mathrm{WCHF}$ and is $309.5 \%$ better than the unreinforced LDPE polymer. The least enhancement is given by the LDPE composite reinforced with 0.15 $\mathrm{M} \mathrm{KOH}$-treated $4 \mathrm{wt} \% \mathrm{BCHF}$ and it is still better than the unreinforced LDPE by $5.835 \%$. The tensile stress at break of the LDPE composite reinforced with $0.15 \mathrm{M} \mathrm{NaOH}$-treated $2 \mathrm{wt} \%$ WHCF which has the highest ultimate tensile strength improved by $67.73 \%$. This significant improvement in the fracture strengths of the LDPE 


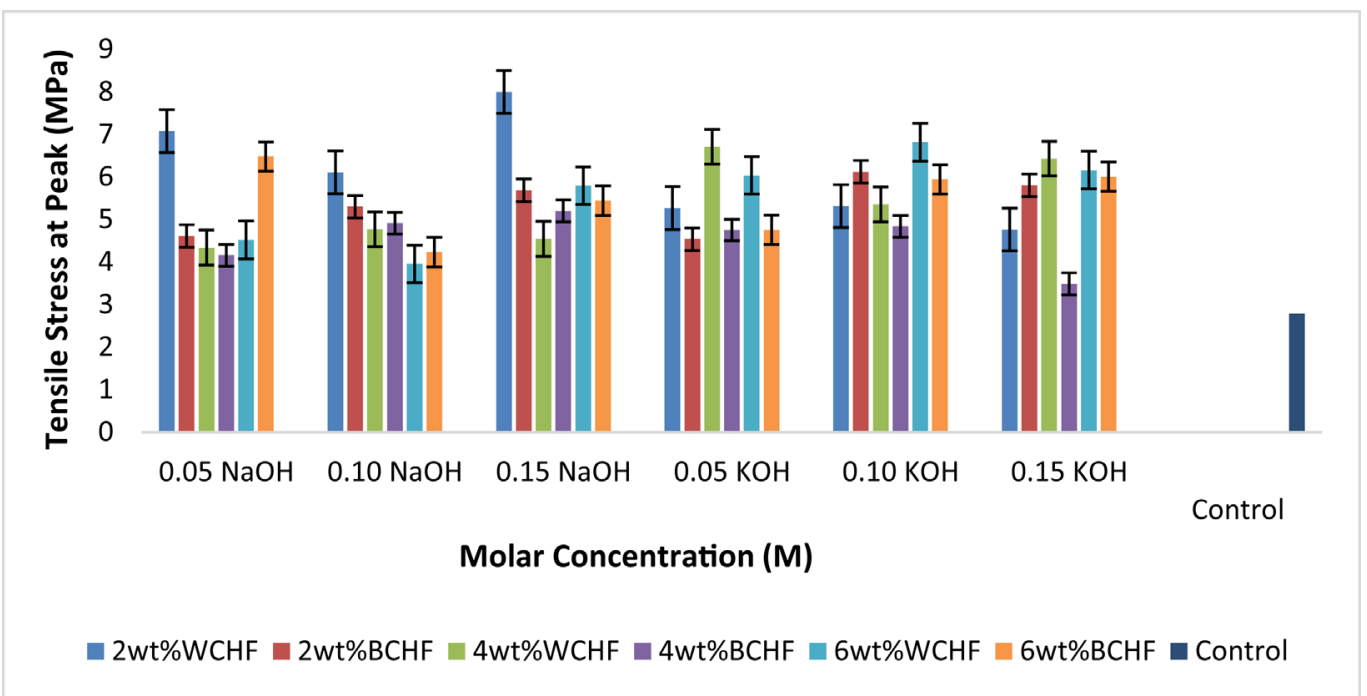

Figure 1. Variation of tensile stress at peak with molar concentrations of the chemical treatments for the LDPE composites and the unreinforced LDPE (control).

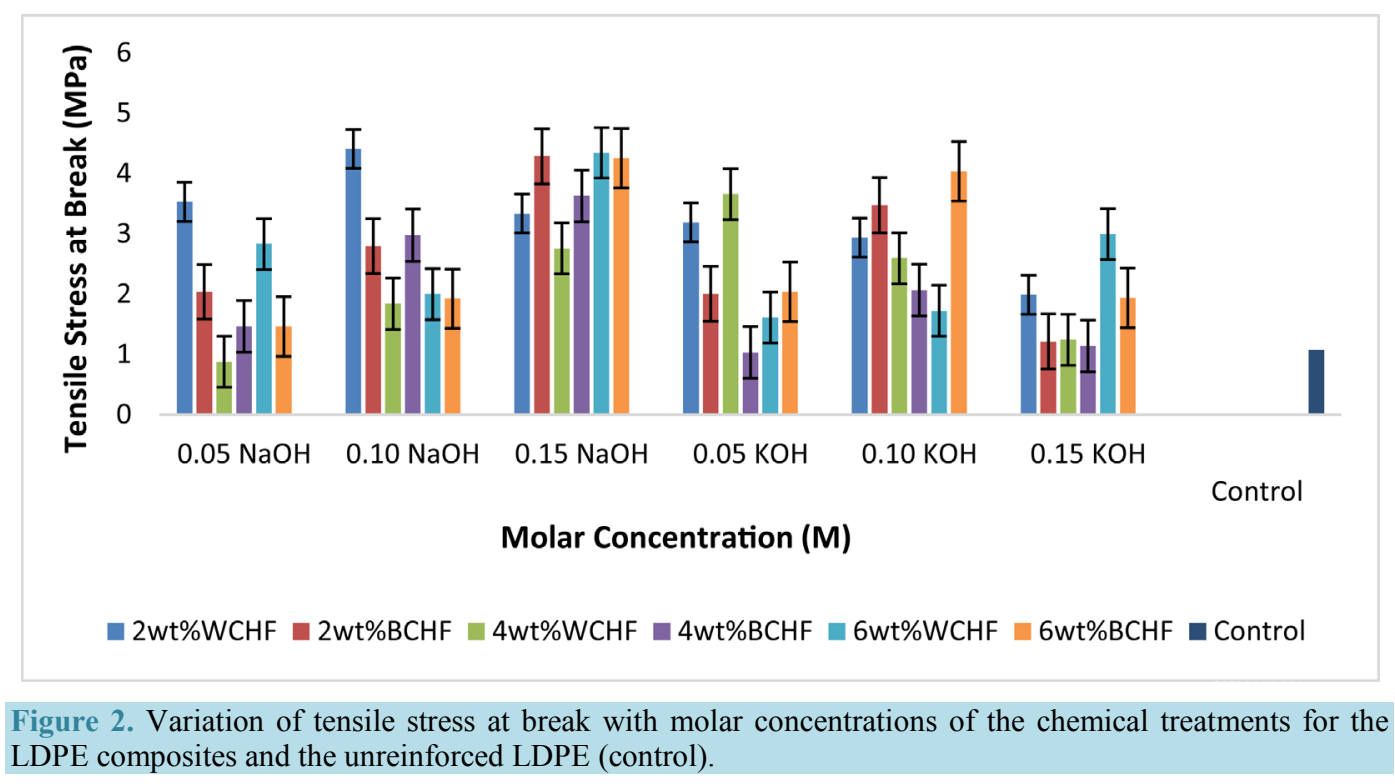

composites can be attributed to the key factors discussed comprehensively under Figure 1.

\subsubsection{Tensile Modulus}

The variation of tensile modulus with molar concentrations of the chemical treatments for the LDPE composites and the unreinforced LDPE is presented in Figure 3. Observations from this result revealed that increase in molar concentration of the $\mathrm{NaOH}$ treatement favored increase in tensile moduli of the LDPE composites reinforced with $2-4 \mathrm{wt} \% \mathrm{CHFs}$ and at $6 \mathrm{wt} \%$ fibre loading, the optimum enhancement is at $0.05 \mathrm{M}$. For the $\mathrm{KOH}$ treatment, the tensile moduli of all the LDPE composites increased with increase in molar concentration from $0.05 \mathrm{M}$ to $0.10 \mathrm{M}$. The trend of the consistency is interrupted at $0.15 \mathrm{M}$. The superlative enhancement is presented by the LDPE composite reinforced with $0.10 \mathrm{M} \mathrm{KOH}$-treated $6 \mathrm{wt} \% \mathrm{WCHF}$ and it has a tensile modulus which is better than that of the unreinforced LDPE by $160.70 \%$. The least enhancement is given by the LDPE composite reinforced with $0.05 \mathrm{M} \mathrm{NaOH}$-treated $4 \mathrm{wt} \%$ WCHF with a tensile modulus that supersedes that of the unreinforced LDPE by $5.203 \%$. The tensile modulus of the LDPE composite reinforced with $0.15 \mathrm{M}$ $\mathrm{NaOH}$-treated $2 \mathrm{wt} \%$ WCHF which has the highest ultimate tensile strength improved by $119.04 \%$. 


\subsubsection{Tensile Strain at Break}

The variation of tensile strain at break with molar concentrations of the chemical treatments for the LDPE composites and the unreinforced LDPE is presented in Figure 4. Observations from this result revealed that there is no consistency in the trend of increase in molar concentrations of both chemical treatments and increase in strain to fracture of the developed LDPE composites. The superlative performance is demonstrated by the same LDPE composite with the highest ultimate tensile strength, its strain to fracture is $80.86 \%$ better than that of the unreinforced LDPE. The least enhancement is given by the $0.10 \mathrm{M} \mathrm{KOH}$-treated $2 \mathrm{wt} \% \mathrm{WCHF}$ reinforcement with $4.35 \%$ betterment in comparison with the unreinforced LDPE.

\subsection{Fracture Behaviour}

The fracture behaviour and failure mode of the LDPE composites are presented in Figure 5. The results revealed shearing of the LDPE composite at the fibre-matrix interface which implies that the applied tensile stress

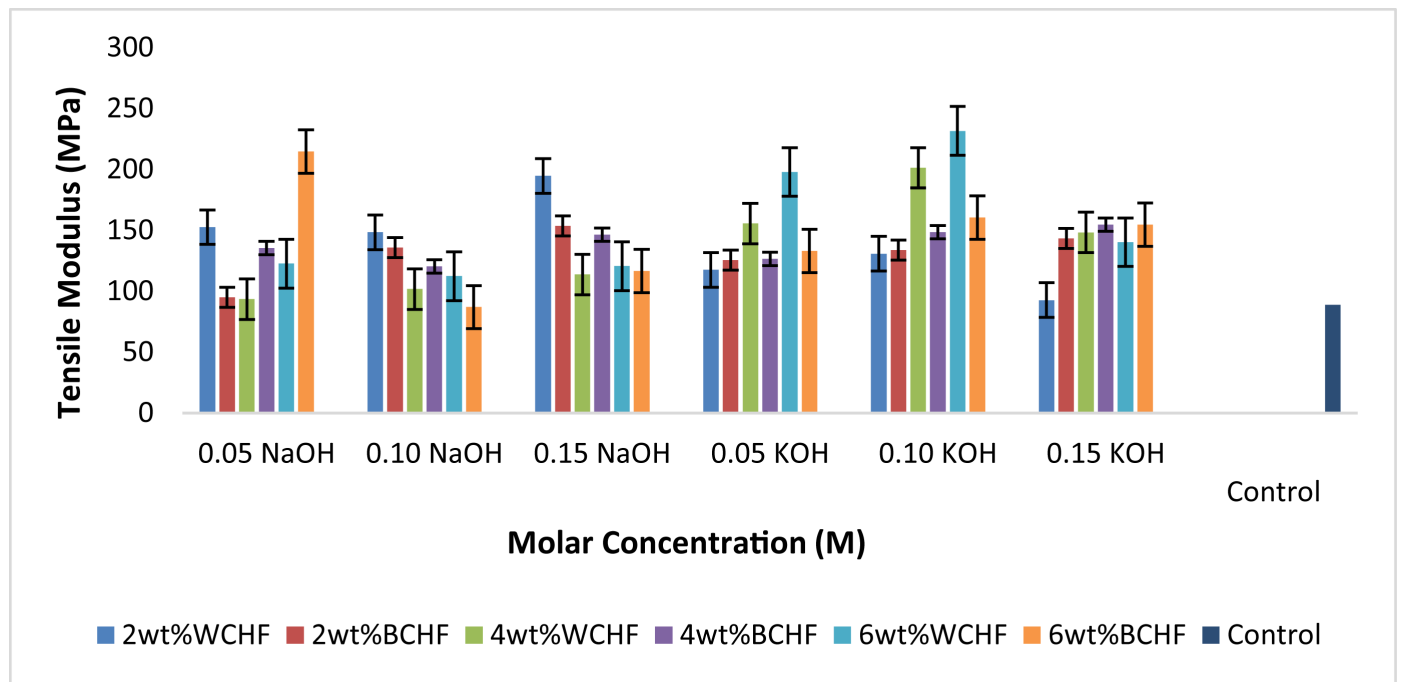

Figure 3. Variation of tensile modulus with molar concentrations of the chemical treatments for the LDPE composites and the unreinforced LDPE (control).

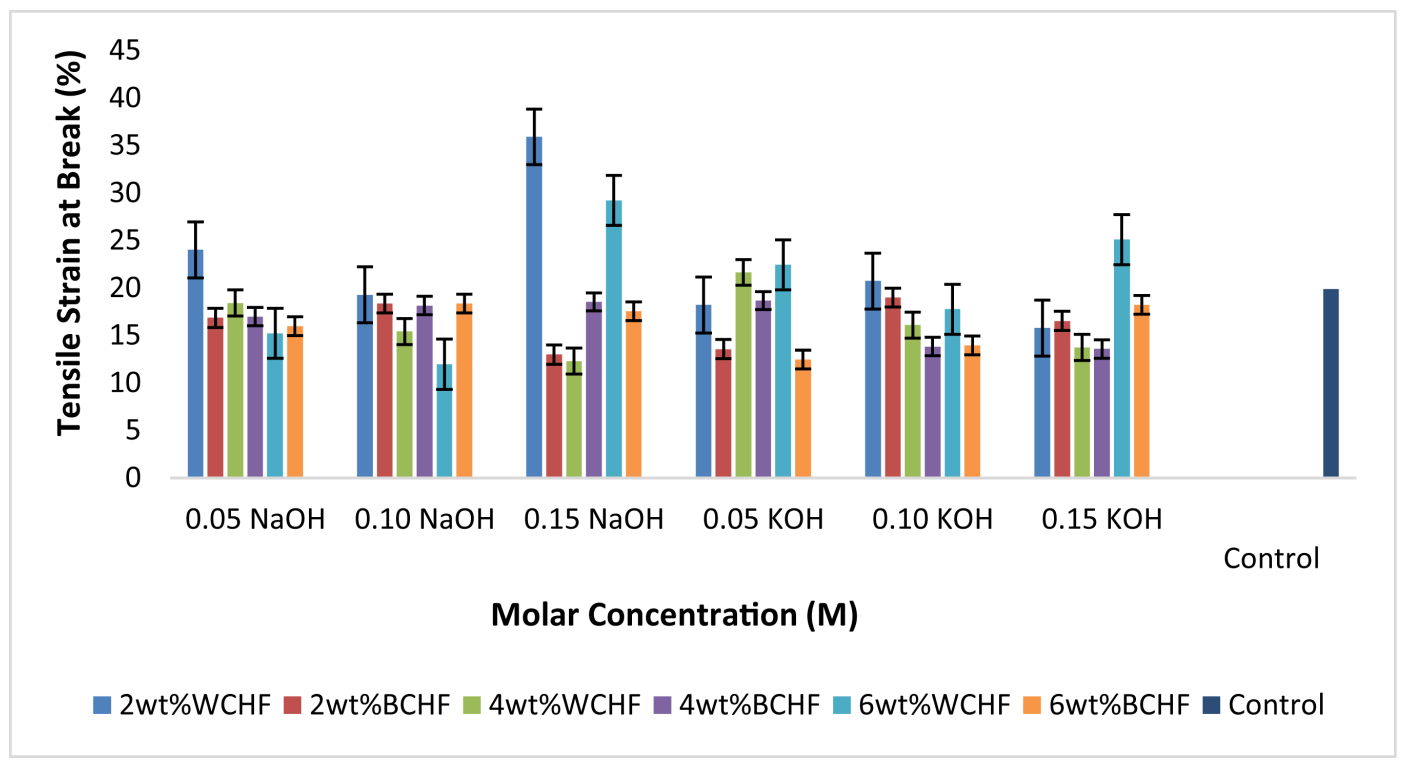

Figure 4. Variation of tensile strain at break with molar concentrations of the chemical treatments for the LPDE composites and the unreinforced LDPE (control). 


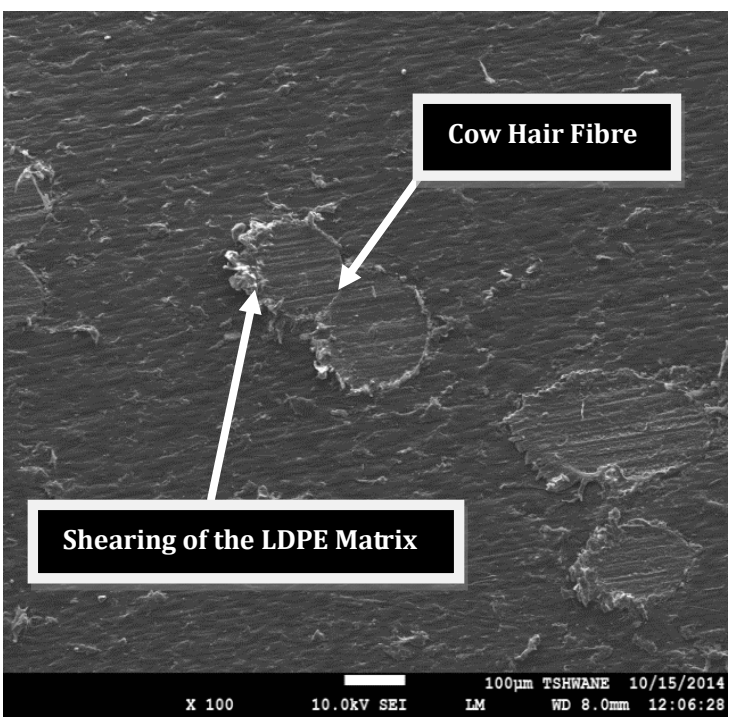

(a)

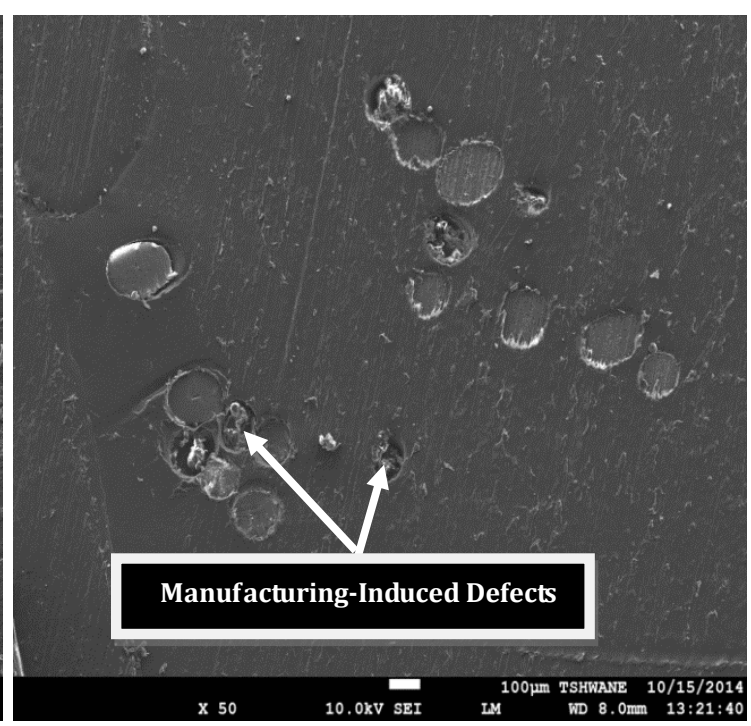

(b)

Figure 5. SEM Images of the fractured surface of composites after tensile loading (a) NaOH-treated CHF; (b) KOHtreated $\mathrm{CHF}$.

stretched the LDPE polymer matrix more than the reinforcing CHFs [45] (Figure 5(a)). This is a clear indication that the developed CHF-reinforced LDPE composites are not susceptible to catastrophic failure under tensile loading. The image in Figure 5(b) shows manufacturing-induced defects that might have arose during the development of the composites due to air entrapment.

\section{Conclusions}

This investigation has been conducted to reassess the economic importance of cow hair fibres, establish their suitability and reinforcing efficiency in composite materials. From the research findings, it was observed that:

- Both treatments led to excellent performance in tensile properties. Considering the selected chemicals, tensile properties were better enhanced by treating the $2 \mathrm{wt} \%$ CHF reinforcement with $0.15 \mathrm{M} \mathrm{NaOH}$ and the 6 wt $\%$ reinforcement with $0.1 \mathrm{M} \mathrm{KOH}$;

- The best molar concentration for the treatment of cow hair fibre intended for the reinforcing phase of LDPE was discovered to be $0.15 \mathrm{M}$ for $\mathrm{NaOH}$ while $0.05-0.1 \mathrm{M}$ was the best for $\mathrm{KOH}$;

- The best \% fibre loadings for these treatments laid between 2 - $4 \mathrm{wt} \%$ for $\mathrm{NaOH}$ and $6 \mathrm{wt} \%$ for $\mathrm{KOH}$;

- Animal fibres should be treated with the best alkaline solution before they were used as reinforcement in composite materials development owing to the fact that chemical treatments had the potential of enhancing the properties of developed composites. The selected alkaline concentrations and the $\%$ fibre loading used revealed that high concentration and low fibre volume fraction favoured the use of $\mathrm{NaOH}$ while low concentration and high fibre volume fraction favoured the use of $\mathrm{KOH}$ treatment.

For engineering application where high tensile strength and high ductility of low density polyethylene are required, $0.15 \mathrm{M} \mathrm{NaOH}$-treated WHCF reinforced-LDPE should be used in lieu of unreinforced LDPE, and in applications where moderate strength and high stiffness are required, $0.1 \mathrm{M} \mathrm{KOH}$-treated $6 \mathrm{wt} \% \mathrm{WCHF}$ reinforcement should be used.

\section{References}

[1] Valesco, M.V.R., Dias, T.C., Zanardi de Feritas, A., Vieira Junior, N.D., Pinto, C.A.S., Kaneko, T.M. and Baby A.R. (2009) Hair Fibre Characteristics and Methods to Evaluate Hair Physical and Mechanical Properties. Brazilian Journal of Pharmaceutical Science, 45, 153-156. http://dx.doi.org/10.1590/S1984-82502009000100019

[2] Seshadri, I. and Bhushan, B. (2008) In Situ Tensile Deformation Characterization of Human Hair with Atomic Force Microscopy. Acta Materiala, 56, 774-781. http://dx.doi.org/10.1016/j.actamat.2007.10.033

[3] Dias, M.F.R.G. (2015) Hair Cosmetics: An Overview. International Journal of Trichology, 7, 2-15. 
http://dx.doi.org/10.4103/0974-7753.153450

[4] Khan, I., Maldonado, E., Vasconcelos, V., J O’Brien, S., Johnson. W.E. and Antunes, A. (2014) Mammalian Keratin Associated Proteins (KRTAPs) Subgenomes: Disentangling Hair Diversity and Adaptation to Terrestrial and Aquatic Environments. BMC Genomics, 15, 779. http://dx.doi.org/10.1186/1471-2164-15-779

[5] Yang, F., Zhang, Y. and Rheinstadter, M.C. (2014) The Structure of People's Hair. PeerJ, 2, e619. http://dx.doi.org/10.7717/peerj.619

[6] Ramot, Y. and Zlotogorski, A. (2015) Keratin: The Hair Shaft's Backbone Revealed. Experimental Dermatology, 24, 416-417. http://dx.doi.org/10.111/exd.12654

[7] Sinclair, D.R. (2007) Healthy Hair: What Is It? Journal of Investigative Dermatology Symposium Proceedings, 12, 2-5. http://dx.doi.org/10.1038/sj.jidsymp.5650046

[8] McMullen, R. and Jachowicz, J. (1998) Thermal Degradation of Hair. I. Effect of Curling Irons. Journal of Cosmetic Science, 49, 223-244.

[9] Nagasawa, T., Suzuki, H., Koyama, M., Sato, T., Kawamura, K. and Yamaguchi, Y. (2013) Development of a Novel Penetration-Enhancing Agent for Hair Products. Journal of Cosmetics, Dermatological Sciences and Applications, 3, 129-134. http://dx.doi.org/10.4236/jcdsa.2013.31020

[10] Oladele, I.O., Olajide, J.L. and Ogunbadejo, A.S. (2015) Effect of Chemical Treatments on the Physicochemical and Tensile Properties of Cow Hair Fibres for Low Load Bearing Composites Development. International Journal of Materials Science and Applications, 4, 189-197.

[11] Batebi, Y., Mirzagoltabar, A., Shabanian, S.M. and Fateri, S. (2013) Experimental Investigation of Shrinkage of Nano Hair Reinforced Concrete. Iranica Journal of Energy \& Environment, Special Issue on Nanotechnology, 4, 68-72.

[12] Oladele, I.O., Omotoyinbo, J.A. and Ayemidejor, S.H. (2014) Mechanical Properties of Chicken Feather and Cow Hair Fibre Reinforced High Density Polyethylene Composites. International Journal of Science and Technology, 3, 66-71.

[13] (2015) Brief History of Concrete. http://www.djc.com/special/concrete/10003364.htm

[14] Erdogmus, E. (2015) Use of Fiber-Reinforced Cements in Masonry Construction and Structural Rehabilitation: Review. Fibers, 3, 41-63. http://dx.doi.org/10.3390/fib3010041

[15] Gani, M.S.J. (1997) Cement and Concrete. Chapman \& Hall, London.

[16] NIIR Board of Consultants and Engineers (2006) The Complete Technology Book on Fibre Glass, Optical Glass and Reinforced Plastics. Asian Pacific Business Press Inc., Delhi.

[17] Masuelli, M.A. (2013) Introduction of Fibre-Reinforced Polymers-Polymer and Composites: Concepts, Properties and Process. InTech, Croatia, 1-24.

[18] Hardin, A.L. (1990) Industry Structure and the Marketing of Synthetic Fibres. Business and Economic History, Second Series, 19, 213-222.

[19] Fowler, P.A., Hughes, J.M. and Elias, R.M. (2006) Review Biocomposites: Technology, Environmental Credentials and Market Forces. Journal of the Science of Food and Agriculture, 86, 1781-1789. http://dx.doi.org/10.1002/jsfa.2558

[20] Liu, Y., Yu, X., Li, J., Fan, J., Wang, M., Lei, T., Liu, J. and Huang, D. (2015) Fabrication and Properties of HighContent Keratin/Poly (Ethylene Oxide) Blend Nanofibers Using Two-Step Cross-Linking Process. Journal of Nanomaterials, 2015, Article ID: 803937. http://dx.doi.org/10.1155/2015/803937

[21] Barone, J.R. and Schmidt, W.F. (2004) Polyethylene Reinforced with Keratin Fibers Obtained from Chicken Feathers. Composites Science and Technology, 65, 173-181.

[22] Dwivedi, A.K., Darbari, A.S. and Verma, V.K. (2015) Compressive Strength Evaluation of Human Hair and Polypropylene Fabricated Reinforced Composite. The International Journal of Engineering and Science, 4, 88-91.

[23] Oladele, I.O., Olajide, J.L. and Ogunbadejo, A.S. (2015) The Influence of Chemical Treatment on the Mechanical Behaviour of Animal Fibre-Reinforced High Density Polyethylene Composites. American Journal of Engineering Research, 4, 19-26.

[24] Dynalab Corp (2015) Plastic Properties of Low Density Polyethylene (LDPE). http://www.dynalabcorp.com/technical info ld polyethylene.asp

[25] Ceresana Market Intelligence. Consulting (2015) Market Study: Polyethylene LDPE. 2nd Edition. http://www.ceresana.com/en/market-studies/plastics/polyethylene-ldpe/

[26] United Plastic Components (2015) LDPE (Low Density Polyethylene). http://www.upcinc.com/resources/materials/LDPE.html

[27] Plastixportal, Plastics \& Packaging Directory (2015) Low Density Polyethylene Material Properties. http://www.plastixportal.co.za/LDPE Low Density Polyethylene.html 
[28] Jahan, A., Rahman, M.M., Kabir, H., Kabir, M., Ahmed, F., Hossain, M. and Gafur, M. (2013) Optical, Electrical and Thermal Properties of Jute and Glass Fiber Reinforced LDPE Composites. International Journal of Basic and Applied Science, 2, 482-490.

[29] Shamsuri, A.A., Azid, M.K.A., Ariff, A.H.M. and Sudari, A.K. (2014) Influence of Surface Treatment on Tensile Properties of Low-Density Polyethylene/Cellulose Woven Biocomposites: A Preliminary Study. Polymers, 6, 23452356. http://dx.doi.org/10.3390/polym6092345

[30] Sabet, M. and Soleimani, H. (2014) Mechanical and Electrical Properties of Low Density Polyethylene Filled with Carbon Nanotubes. IOP Conference Series: Materials Science and Engineering, 64, Article ID: 012001. http://dx.doi.org/10.1088/1757-899x/64/1/012001

[31] GEMS (Growth \& Employment in States) (2012) Brief: Transforming the Nigerian Beef Industry. http://www.gemsnigeria.com/wordpress/wp-content/uploads/2012/GEMS1Brief_BeefIndustryTransformation-4page.p df

[32] FAO (Food and Agricultural Organization) (1985) Manual for the Slaughter of Small Ruminants in Developing Countries: Slaughtering Practices and Techniques. FAO Animal Production and Health Paper, Chap. 6, 49.

[33] Gounna Corp (2013) Expert Urges Govt, Others to Embrace Local Content. http://www.nigeria.gounna.com/show/show/38590/1

[34] Li, X., Tabil, L.G. and Panigrahi, S. (2007) Chemical Treatments of Natural Fibers for Use in Natural Fiber-Reinforced Composites: A Review. Journals of Polymers and the Environment, 15, 25-33. http://dx.doi.org/10.1007/s10924-006-0042-3

[35] Olayemi, I.K., Idris, B., Ejima, I.A.A., Adeniyi, K., Ukubuiwe, A.C. and Isah, B. (2014) The Climate of North-Central Nigeria and Potential Influence on Mosquito (Diptera: Culicidae) Vectorial Capacity, for Disease Transmission. Global Journal of Multidisciplinary and Applied Sciences, 2, 26-31.

[36] ASTM D412 (1983) Standard Test Methods for Vulcanized Rubber and Thermoplastic Elastomers-Tension. American Society for Testing and Materials.

[37] Ramadevi, P., Sampathkumar, D., Srinivasa, C.V. and Bennehalli, B. (2012) Effect of Alkali Treatment on Water Absorption of Single Cellulosic Abaca Fiber. BioResources, 7, 3515-3524.

[38] Farsi, M. (2012) Thermoplastic Matrix Reinforced with Natural Fibers: A Study on Interfacial Behavior, Some Critical Issues for Injection Molding. In: Wang, J., Ed., Some Critical Issues for Injection Molding, Chap. 10, InTech, 225-250. http://www.cdn.intechopen.com/pdf-wm/33652.pdf

[39] Fuentes, C., Brughmans, G., Tran, L.Q.N., Dupont, C., Verpoest, I. and Vuure, A.W.V. (2015) Mechanical Behaviour and Practical Adhesion at a Bamboo Composite Interface: Physical Adhesion and Mechanical Intrlocking. Composites Science and Technology, 109, 40-47. http://dx.doi.org/10.1016/j.compscitech.2015.01.013

[40] Lin, T., Jia, D., He, P., Wang, M. and Liang, D. (2008) Effects of Fiber Length on Mechanical Properties and Fracture Behaviour of Short Carbon Fiber Reinforced Geopolymer Matrix Composites. Materials Science and Engineering, 494, 181-185. http://dx.doi.org/10.1016/j.msea.2008.06.040

[41] Amuthakkannan, P., Manikandan, V., Winowlin Jappes, J.T. and Uthayakumar, M. (2013) Effect of Fibre Length on Mechanical Properties of Short Basalt Fibre Reinforced Polymer Matrix Composites. Materials Physics and Mechanics, 16, 107-117.

[42] Gibson, R.F. (1994) Principles of Composite Material Mechanics. McGraw-Hill Inc., St. Louis.

[43] Kaw, A.K. (2006) Mechanics of Composite Materials. 2nd Edition, Taylor \& Francis, Boca Raton.

[44] Boresi, A.P. and Schmidt, R.J. (2003) Advanced Mechanics of Materials. 6th Edition, John Wiley \& Sons, New York.

[45] Greenhalgh, E.S. (2009) Failure Analysis and Fractography of Polymer Composites. Woodhead, Cambridge. 